\title{
IMPACT OF MULTIPATH GPS SIGNAL SPREADING ON PRECISION OF USER LOCALIZATION
}

\author{
Jozef CHRASTINA, Tomáš POLONEC, Ivan JANOŠKO, Juraj TULÍK
}

Slovak University of Agriculture in Nitra, Slovakia

\begin{abstract}
This paper focuses on measuring the inaccuracy of localization using a global positioning system. It describes the types and causes of navigation errors as well as the impact of multipath signal spreading on determining the GPS location. The aim of the experiment is to quantify the degree of influence of GPS multipath signal spreading in urban environments compared with measurements in the open air. During the experiment, we have used a Holux M-1000C GPS device in the DGPS / SBAS mode using the EGNOS technology.
\end{abstract}

Keywords: GPS, GPS data logger, multipath

The global positioning system (GPS) is a system designated for an exact user's localization anywhere on the Earth. With this system, navigation to specific geographic coordinates is easier. However, when the user repeats the detection of a single point, the system always shows different coordinates. Current detected position is different from the actual always with some deviation. The accuracy of these devices is influenced by several factors such as intentionally and artificially inserted errors caused during signal transfer. In general, measurement errors can be divided into two main groups, namely:

- random measurement errors,

- systematic measurement errors.

Random errors are errors the absolute value of which varies according to the law of probability distribution. Random errors of measurement cannot be excluded, we can only estimate their characteristics.

Systematic errors are mostly the same. They occur with each measurement and the measurement result of these errors is always distorted in some way. During an ordinary measurement, they cannot be excluded but only compensated by additional systems such as the European system EGNOS (European Geostationary Navigation Overlay

Table 1 Location errors of GPS with and without DGPS

\begin{tabular}{|c|c|c|}
\hline $\begin{array}{l}\text { Causes and types } \\
\text { of errors }\end{array}$ & $\begin{array}{l}\text { Errors without } \\
\text { DGPS in } \mathbf{m}\end{array}$ & $\begin{array}{l}\text { Errors with DGPS } \\
\text { in } \mathbf{m}\end{array}$ \\
\hline Ephemeris error & 1.5 & 0.1 \\
\hline $\begin{array}{l}\text { Impact of } \\
\text { ionosphere }\end{array}$ & 3 & 0.2 \\
\hline $\begin{array}{l}\text { Impact of } \\
\text { troposphere }\end{array}$ & 0.7 & 0.2 \\
\hline $\begin{array}{l}\text { Impact of satellite } \\
\text { atom clock }\end{array}$ & 1.5 & 0.1 \\
\hline $\begin{array}{l}\text { Multipath signal } \\
\text { spreading }\end{array}$ & 1 & 1.4 \\
\hline Rounding errors & 0.5 & 0.5 \\
\hline Total error value & 8.2 & 2.5 \\
\hline
\end{tabular}

Service) or North American WAAS (Wide Area Augmentation System), etc. These systems emit a signal of the exact position of transceivers at the same frequency as satellites. Using these technologies, we use a differential correction of measured values (DGPS) and thus the measurement precision is increasing. The table shows the types and causes of errors and approximate deviations of GPS navigation with and without signal correction.

The objective of the experiment is to determine the level of navigation inaccuracy caused by multipath signal spreading (Figure 1), or inaccuracy with which you can navigate and record any position in an urban environment.

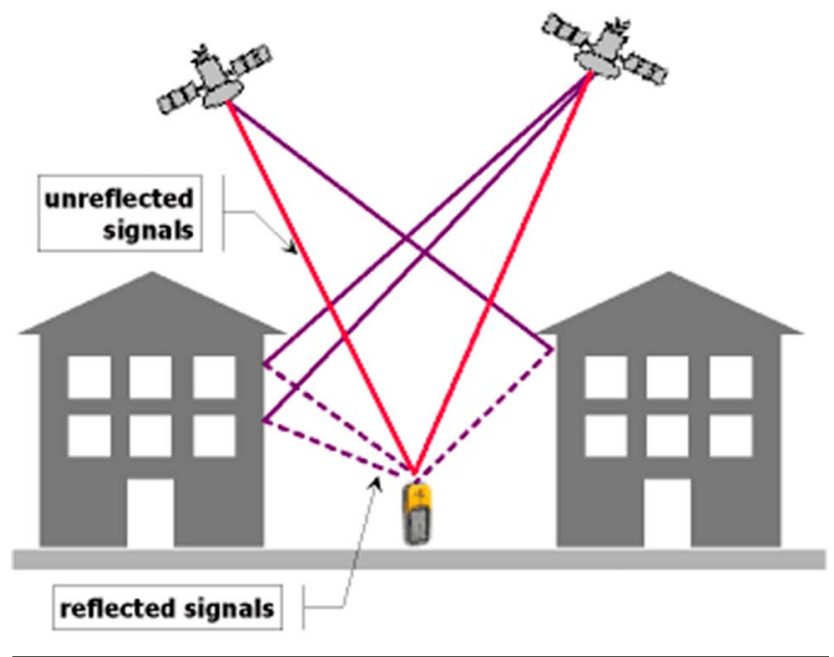

Figure 1 Multipath spreading of GPS signal Resource: www.kowoma.de, 2013

\section{Material and methods}

For recording of geographic locations, we have used the Holux M-1000C GPS data logger (Figure 2) with a 32-channel MTK MT3318 chipset and an internal memory of 128 megabytes. The manufacturer declares a very good sensitivity of the antenna (around $165 \mathrm{dBm}$ ) and, under 

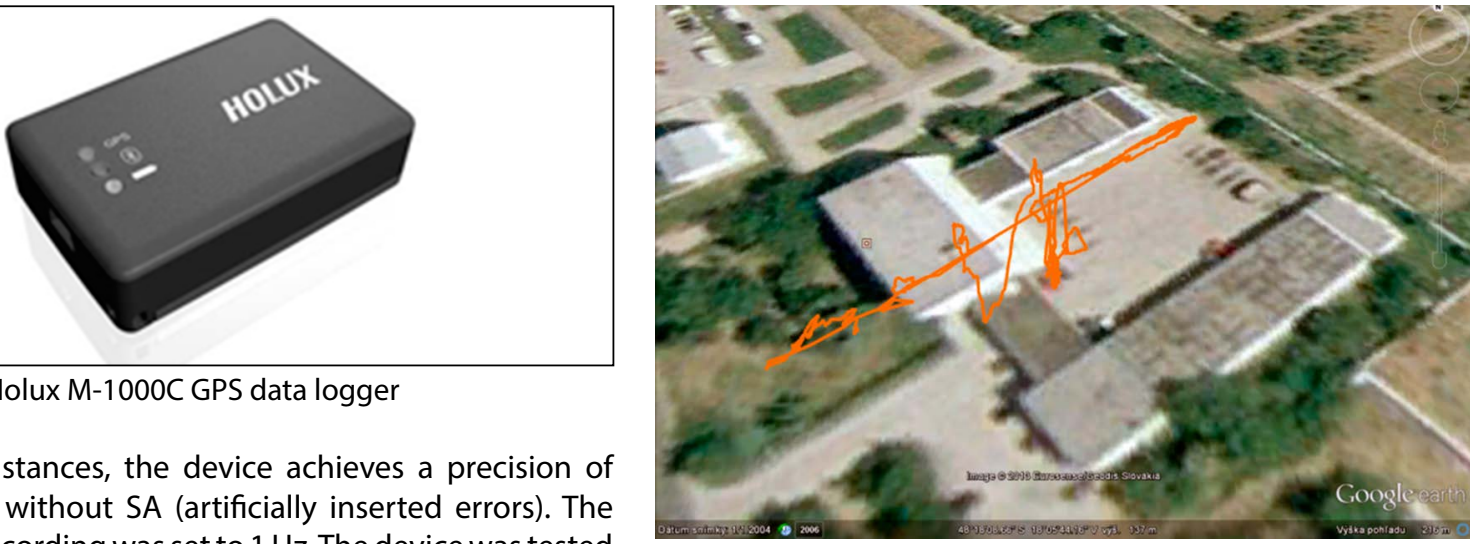
less than $3 \mathrm{~m}$ without SA (artificially inserted errors). The frequency of recording was set to $1 \mathrm{~Hz}$. The device was tested in the DGPS / SBAS mode using the EGNOS technology.

Because satellites orbit the Earth at an interval of about $24 \mathrm{~h}$ and to ensure constant atmospheric conditions, measurements were made always at the same time $(9.00 \mathrm{~h}$ UTC), for a period of 30 minutes in a series of 3 repetitions, on 22-27 April 2012. Figure 3 shows the atmospheric conditions during the experiment.

Measured values were transferred from the device's memory to the PC and statistically processed in MS Excel.

\section{Results and discussion}

Experimental measurements were performed by the system of stationary point. As the first measurement place, we have chosen an urban built-up area (indicated in the tables as no. 1). The actual shape of buildings ensured a multipath spreading of signal (Figure 4 left). This noise caused the reflection of locational signals, which created inaccuracy in determining the correct localization of the receiver.

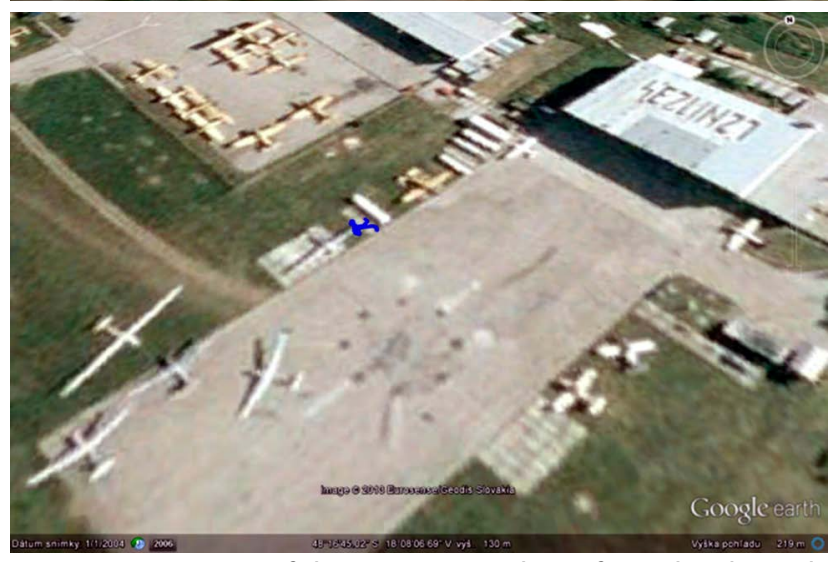

Figure $4 \quad$ View of the measuring places from the sky with visualization of measured coordinates (scales are identical) - measuring place no. 1 (upper figure), measuring place no. 2 (lower figure)

For comparison of results, we have chosen as the second measurement place an outlying area near the city of Nitra,

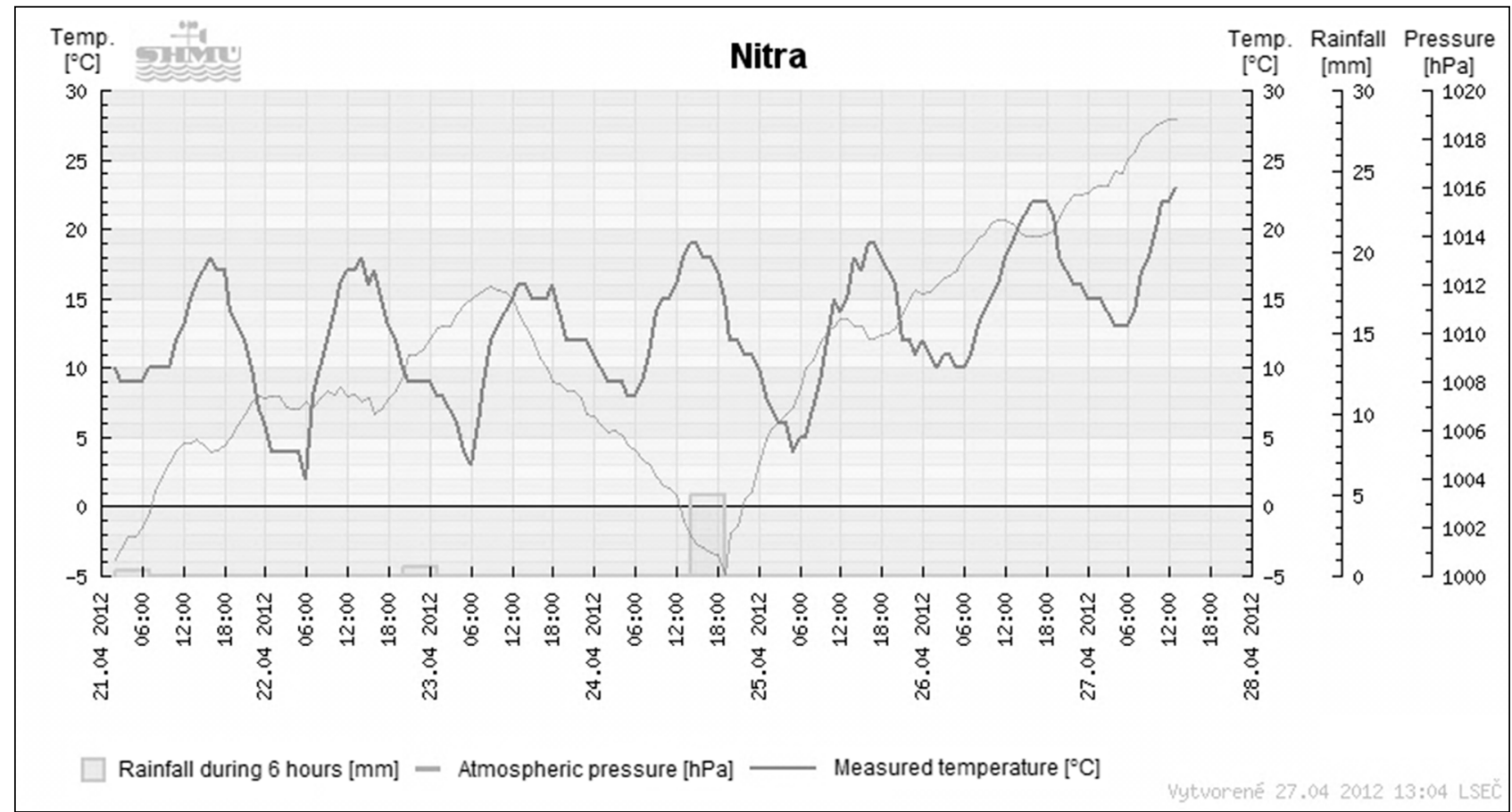

Figure 3 Meteorological conditions during the experiment

Resource: Slovenský hydrometeorologický ústav, 2012 
Table 2

\begin{tabular}{|l|c||c|c|c|c|}
\hline \multirow{2}{*}{ Date } & \multirow{2}{*}{$\begin{array}{c}\text { Measuring } \\
\text { place }\end{array}$} & \multicolumn{4}{|c|}{ Arithmetic mean of values of measured position } \\
\cline { 3 - 6 } & & $\begin{array}{c}\text { latitude } \\
\text { (DD'MM.mm') }\end{array}$ & $\begin{array}{c}\text { longitude } \\
\text { (DD'MM.mm') }\end{array}$ & $\begin{array}{c}\text { deviation from mean } \\
\text { value of position in } \mathbf{~ m}\end{array}$ & $\begin{array}{c}\text { deviation from } \\
\text { altitude in } \mathbf{~ m}\end{array}$ \\
\hline \hline 22.4 .2012 & 1 & 4818.146 & 1805.724 & 37.532 & $-1.514-12$ \\
\hline 23.4 .2012 & 2 & 4816.759 & 1808.105 & 2.138 & 2.0418 \\
\hline 24.4 .2012 & 1 & 4818.146 & 1805.724 & 35.0631 & 1.447 \\
\hline 25.4 .2012 & 2 & 4816.758 & 1808.105 & 1.836 & 3.174 \\
\hline 26.4 .2012 & 2 & 4816.759 & 1808.104 & 1.967 & 2.787 \\
\hline 27.4 .2012 & 1 & 4818.146 & 1805.723 & 31.220 & 9.536 \\
\hline
\end{tabular}

Table 3 Variance of coordinates in each measuring days

\begin{tabular}{|l|c||c|c|}
\hline \multirow{2}{*}{ Date } & \multirow{2}{*}{$\begin{array}{c}\text { Measuring } \\
\text { place }\end{array}$} & \multicolumn{2}{c||}{ Variance of measured values of position } \\
\cline { 2 - 4 } & deviation from mean value of position in $\mathbf{~ m}$ & deviation from altitude in $\mathbf{~ m}$ \\
\hline \hline 22.4 .2012 & 1 & 17.241 & 21.824 \\
\hline 23.4 .2012 & 2 & 0.564 & 1.0663 \\
\hline 24.4 .2012 & 1 & 14.785 & 19.0563 \\
\hline 25.4 .2012 & 2 & 0.0364 & 0.0417 \\
\hline 26.4 .2012 & 2 & 0.451 & 0.612 \\
\hline 27.4 .2012 & 1 & 9.629 & 11.159 \\
\hline
\end{tabular}

with a clear view of the sky (satellites) (this area is indicated in the tables as no. 2), and without interference of the reflected signal.

The results of measurements are shown in Tables 2 and 3. In Figures 5, 6 and 7, there are shown exemplary waveforms from 22 April 2012 (measuring place no. 1) and from 25 April 2012 (measuring place no. 2).

As mentioned on the website www.kowoma.de (2013), the reflected signal causes noise, noise similar to that on an analogue TV ('ghosts'), and so it causes localization inaccuracy in the order of several metres. We can see from Tables 2 and 3 that the arithmetic mean and variance of values measured in the urban environment (place no. 1) is relatively large, on average $34.605 \mathrm{~m}$. These inaccuracies are caused by parasitic signals (radio waves) from GPS satellites reflected from surrounding buildings. In contrast, values obtained in the outlying area without barriers (place no. 2)

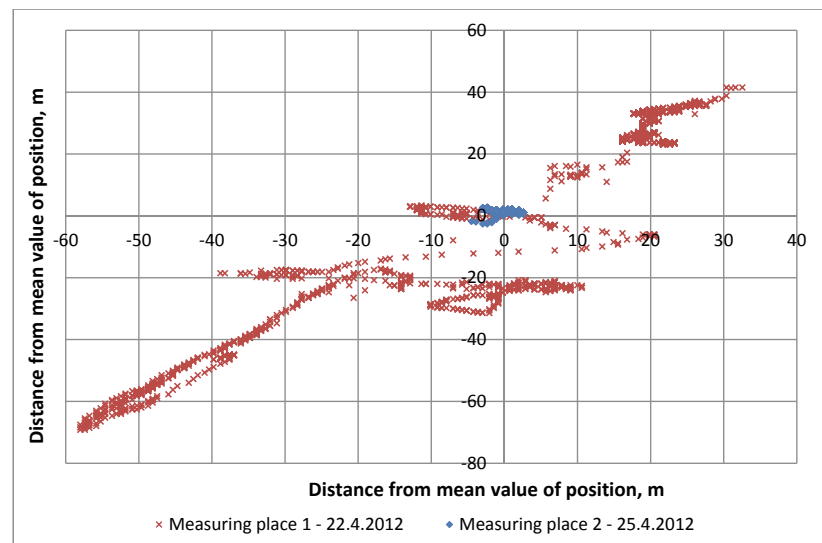

Figure 5 Record of layouts of errors in the horizontal plane

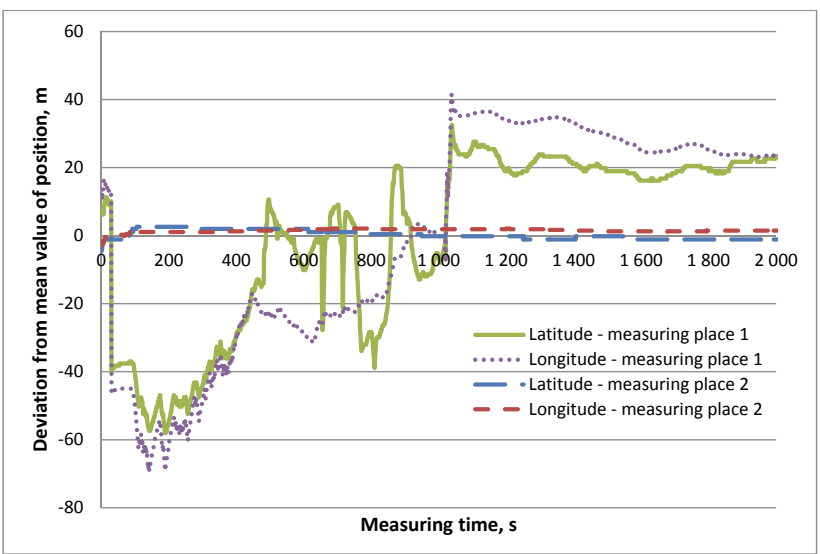

Figure 6 Deviation of geographical coordinates from mean calculated values

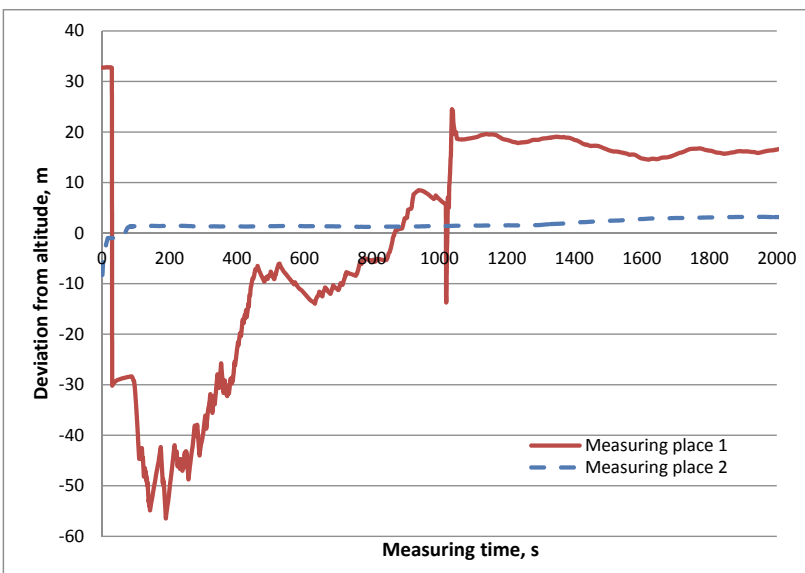

Figure 7 Change of deviations of altitude from mean calculated values 
were not affected by surrounding buildings and therefore the signal is relatively accurate, with a minimal deviation of $1.98 \mathrm{~m}$ on average. This variation is consistent with the declared maximum deviation from the manufacturer.

In Figure 5, there are recorded coordinates converted to metres. The $x$-axis in this figure represents longitude, and the $y$-axis represents latitude. The centre of the coordinate system is the arithmetic mean of all values recorded on one measurement day. Satellites are constantly orbiting, causing that calculated position is constantly changing over time.

Therefore, Figure 6 shows deviations of individual axes over time. Here, we can observe almost identical deviations as for longitude, latitude, and even altitude (Figure 7).

From the above waveforms, we see that the multipath spreading of localization signal from satellites has a considerable impact on systematic errors in measurements. As reported by Hodoň (2010), high ringing at the beginning of measurement is caused by cold start or, in other words, by time-to-first-fix (TTFF) of GPS receiver. In our case, the manufacturer states $36 \mathrm{~s}$. This time is necessary to synchronize the internal clock of the receiver and to verify all data received from satellites (Šimerda, 2011). For that reason, it is necessary to filter the first minute of recording.

\section{Conclusion}

This paper focuses on measuring the impact of multipath spreading of GPS signal. Such signal spreading occurs mainly in urban areas, forest and hilly terrain (Kadleček et al., 2009). Modern navigation systems used primarily in transportation already anticipate a bad localization and reported coordinates of the receiver are fixed to expected route maps (Čupera and Šmerda, 2009; Kadleček et al., 2009). The accuracy of navigation artificially increases in this way. Our calculated accuracies are valid only where the same conditions as in our test are observed. In worse conditions, inaccuracy can be much greater.

\section{Acknowledgement}

This paper was prepared with the support of the project VEGA no. 1/0519/13 'Solution of changes to the technical and exploitative features of mobile energetic resources in terms of using different fuels, their effective use with monitoring of selected technical, energy, environmental and emission parameters'.

\section{References}

ČUPERA, J. - ŠMERDA, T. 2009. Fuel consumption measuring based on CAN-BUS data in comparison of coriolis mass flow meter results. Nitra : SUA, In Advances in Automotive Engineering : proceedings of scientific papers, vol. 2, 2009, pp. 88-92. ISBN 978-80-552-0256-3. HODOŇ, M. 2010. Analýza náhodných zložiek signálu GPS. Available at: http://www.posterus.sk/?p=8876

KADLEČEK, B. - RUŽIČKA, M. - PEJŠA, L. 2009. GPS data processing used for measurement of vehicle's drive dynamics. In: Advances in Automotive Engineering : proceedings of scientific papers, Nitra : SUA, vol. 2, 2009, pp. 72-79. ISBN 978-80-552-0256-3.

KADLEČEK, B. - RUŽIČKA, M. - PEJŠA, L. 2009. The dynamics of drive and fuel consumption. In: Advances in Automotive Engineering : proceedings of scientific papers, Nitra : SUA, vol. 2, pp. 80-87. ISBN 978-80-552-0256-3.

ŠIMERDA, K. 2011. Možnosti zvýšení přesnosti polohy GPS bez pozemní infrastruktury DGPS a odhad polohy při výpadku signálu GPS. Pardubice : Univerzita Pardubice. In Perner's Contacts, vol. 6, 2011, no. 4.

SLOVENSKÝ HYDROMETEOROLOGICKÝ ÚSTAV. 2012. Available at: http://www.shmu.sk

The GPS System. 25.2.2013. Available at: http://www.kowoma.de

\section{Contact address:}

Ing. Jozef Chrastina, Ing. Tomáš Polonec, doc. Ing. Ivan Janoško, CSc., Ing. Juraj Tulík, Slovak University of Agriculture in Nitra, Faculty of Engineering, Department of Transport and Handling, Tr. Andreja Hlinku 2, 94976 Nitra, Slovak Republic, e-mail: jozino.ch@gmail.com, excelentcars@gmail. com, Ivan.Janoško@uniag.sk, juraj.tulik@gmail.com 